\title{
ECOHYDROLOGICAL IMPLICATIONS OF WOODY PLANT ENCROACHMENT
}

\author{
Travis E. Huxman, ${ }^{1,10}$ Bradford P. Wilcox, ${ }^{2}$ David D. Breshears,${ }^{3,11}$ Russell L. Scott,${ }^{4}$ \\ Keirith A. Snyder, ${ }^{5}$ Eric E. Small, ${ }^{6}$ Kevin Hultine, ${ }^{7}$ William T. Pockman, ${ }^{8}$ and Robert B. Jackson ${ }^{9}$ \\ ${ }^{1}$ Ecology and Evolutionary Biology, University of Arizona, Tucson, Arizona 85721-0088 USA \\ ${ }^{2}$ Rangeland Ecology and Management, Texas A\&M University, College Station, Texas 77843 USA \\ ${ }^{3}$ Earth and Environmental Sciences, Los Alamos National Laboratory, University of California, Los Alamos, \\ New Mexico 87545 USA \\ ${ }^{4}$ United States Department of Agriculture, Agricultural Research Service, Southwest Watershed Research Center, Tucson, \\ Arizona 85719 USA \\ ${ }^{5}$ United States Department of Agriculture, Agricultural Research Service, Jornada Experimental Range, Las Cruces, \\ New Mexico 88003-0003 USA \\ ${ }^{6}$ Geological Sciences, University of Colorado, Boulder, Colorado 80309-0399 USA \\ ${ }^{7}$ Department of Biology, University of Utah, Salt Lake City, Utah 84112 USA \\ ${ }^{8}$ Department of Biology, University of New Mexico, Albuquerque, New Mexico 87131-1091 USA \\ ${ }^{9}$ Department of Biology and Nicholas School of the Environment and Earth Sciences, Duke University, Durham, \\ North Carolina 27708-0340 USA
}

Abstract. Increases in the abundance or density of woody plants in historically semiarid and arid grassland ecosystems have important ecological, hydrological, and socioeconomic implications. Using a simplified water-balance model, we propose a framework for conceptualizing how woody plant encroachment is likely to affect components of the water cycle within these ecosystems. We focus in particular on streamflow and the partitioning of evapotranspiration into evaporation and transpiration. On the basis of this framework, we suggest that streamflow and evaporation processes are affected by woody plant encroachment in different ways, depending on the degree and seasonality of aridity and the availability of subsurface water. Differences in landscape physiography, climate, and runoff mechanisms mediate the influence of woody plants on hydrological processes. Streamflow is expected to decline as a result of woody plant encroachment in landscapes dominated by subsurface flow regimes. Similarly, encroachment of woody plants can be expected to produce an increase in the fractional contribution of bare soil evaporation to evapotranspiration in semiarid ecosystems, whereas such shifts may be small or negligible in both subhumid and arid ecosystems. This framework for considering the effects of woody plant encroachment highlights important ecological and hydrological interactions that serve as a basis for predicting other ecological aspects of vegetation change-such as potential changes in carbon cycling within an ecosystem. In locations where woody plant encroachment results in increased plant transpiration and concurrently the availability of soil water is reduced, increased accumulation of carbon in soils emerges as one prediction. Thus, explicitly considering the ecohydrological linkages associated with vegetation change provides needed information on the consequences of woody plant encroachment on water yield, carbon cycling, and other processes.

Key words: carbon cycling; ecohydrology; evapotranspiration; vegetation change; woody plant encroachment.

\section{INTRODUCTION}

Woody plant encroachment into semiarid and arid systems is a global phenomenon with important hydrological and biogeochemical consequences (Houghton et al. 1999, 2001, Schimel et al. 2001). Shrub and

Manuscript received 2 September 2003; revised 19 March 2004; accepted 6 April 2004; final version received 18 May 2004 Corresponding Editor. C. R. Hupp. For reprints of this Special Feature, see footnote 1, p. 275.

${ }^{10}$ E-mail: huxman@arizona.edu

${ }^{11}$ Present address: School of Natural Resources, and Institute for the Study of Planet Earth, University of Arizona, Tucson, Arizona 85721-0043 USA. tree encroachment is often associated with ecosystem degradation-declines in forage productivity, biodiversity, and socioeconomic potential as well as increased erosion (Grover and Musick 1990). Several recent papers have examined the possible consequences of woody plant encroachment on the carbon cycle (Archer et al. 2001, Pacala et al. 2001, Jackson et al. 2002). There has, however, been comparatively little discussion concerning potential hydrological changes that accompany encroachment and their ecological implications. The implications of woody plant encroachment for both water and biogeochemical cycles are poorly understood. 
In this paper, we examine the ecohydrological implications of woody plant encroachment in grasslands and savannahs at the scale of landscapes. Interactions between ecological processes and societal and economic activities at this scale are important, but current understanding of those interactions is incomplete (Chapin et al. 2002). Because of the prevailing focus of research on site-specific factors, and perhaps on smaller-scale changes, ecohydrological generalizations concerning the effects of woody plant encroachment at the landscape scale have been difficult to develop. Here we suggest a framework, composed of two conceptual models, that-by formulating such generalizations across a range of semiarid and arid ecosystem typesimproves our ability to predict the hydrological and ecological consequences of woody plant encroachment. One conceptual model focuses on changes in streamflow; the other on changes in the relative contributions of plant transpiration $(T)$ and soil evaporation $(E)$ to total evapotranspirational flux (ET). The interplay between the two models identifies where ecological processes are important in influencing hydrology, and where hydrologic processes have important ecological implications. In addition, this framework can be used to evaluate other aspects of woody plant encroachment, such as impacts on biogeochemical cycling.

A simplified representation of the water budget, useful for framing the issue, relates major hydrologic fluxes as follows:

$$
P=R+S+\text { ET and ET }=I+E+T
$$

in which $P=$ precipitation, $R=$ runoff, $S=$ deep soil recharge beyond the rooting zone, and $\mathrm{ET}=$ total evapotranspiration, which is equal to the summation of three terms: $I=$ water that is intercepted by plant foliage and assumed to evaporate, $E=$ evaporation from soil, and $T=$ water transpired by plants following soil water uptake. Notably, ET is far larger than $R$ and $S$, usually accounting for $>90 \%$ of $P$ in dryland ecosystems (Wilcox et al. 2003), although small differences in $R$ and $S$ can have ecological, hydrological, or socioeconomic importance. Each of the terms comprising ET can be substantial, although as we will discuss below, the partitioning among them can be quite uncertain. In some environments, deep percolation of soil water $(S)$-past the root zone-may lead to groundwater recharge (see Seyfried et al. [2005] for more detail on recharge in semiarid landscapes). To aid in determining how shifts in vegetation might influence not only the magnitude but other characteristics of these major fluxes, runoff $(R)$ can be further subdivided into overland flow, shallow subsurface flow, and groundwater flow-all of which may contribute to streamflow.

The fundamental questions we seek to address are:

1) Does woody plant encroachment increase ET at the landscape scale enough to affect water supply in the form of streamflow and/or groundwater recharge (water yield)? We are primarily concerned with relatively large changes in water supply to streams as compared to smaller shifts in recharge that may be important for contaminant transport.

2) Even if woody plant encroachment does not increase total ET, does it alter the relative contributions of soil evaporation $(E)$ and plant transpiration $(T)$ to ET? After interception $(I)$ and runoff $(R)$ modify the amount of water that infiltrates into soil, the subsequent partitioning between $E$ and $T$ is the mechanistic link between the hydrologic cycle and ecological characteristics of a landscape. Shifts in $E$ vs. $T$ likely provide insight into ecological processes such as net ecosystem production and carbon cycling that may be influenced by vegetation change.

In addressing these issues, we focus on the two extremes for a given site: (1) little or no woody plant cover and (2) near the maximum amount of woody plant cover that a site can maintain. Further, we focus on impacts of vegetation on the hydrologic cycle at the landscape scale, and thus do not explicitly consider issues related to long-distance water transport through semiarid riparian areas and the effect of vegetation change on that transport. Such exotic streamflow is derived from water abundant areas upstream rather than local precipitation, and therefore is beyond the scope of our site-specific treatment of hydrology based on a simple water budget. Our approach could be expanded to consider intermediate levels of woody plant encroachment and effects of exotic streamflow, but these are beyond the scope of the current paper.

\section{Conceptual Model 1: Effects of Woody Plant ENCROACHMENT ON WATER YIELD}

Whether there is a linkage between woody plant cover and water yield has been extensively investigated in a range of climates. And while such a linkage has been well established for forests in mesic climates (Bosch and Hewlett 1982, Trimble et al. 1987, Stednick 1996), there is less consensus concerning semiarid landscapes (Wilcox 2002, 2003).

Zhang et al. (2001) provide a comprehensive and thoughtful analysis of the influence of vegetation cover on evapotranspiration based on data from over 250 locations globally. They developed a predictive model for mean annual evapotranspiration based on annual rainfall for tree covered areas vs. grass covered areas. We have reproduced the Zhang et al. (2001) model in Fig. 1. For the purposes of this paper we express evapotranspiration (ET) as a percentage of precipitation and show that the effects of woody plants increase as precipitation increases. As a result, woody plants influence ET to a greater extent in more mesic climates and less so in arid climates. In fact, this model predicts a rather substantial rise in ET in humid and subhumid land-

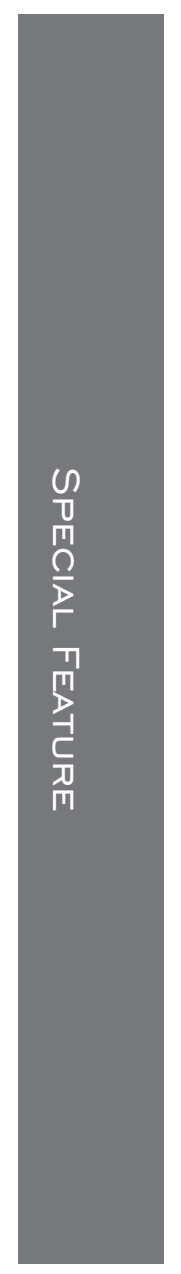




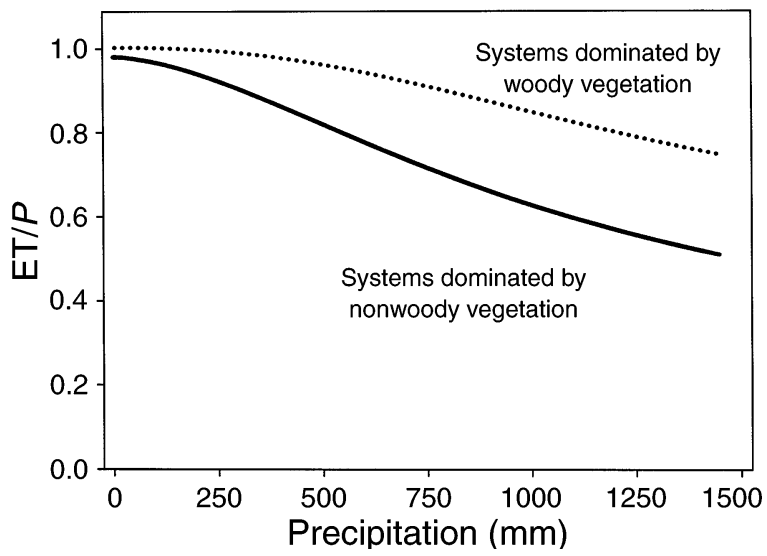

FIG. 1. Evapotranspiration (ET) as a function of precipitation $(P)$ across a precipitation gradient (redrawn from Zhang et al. 2001). The two lines represent ecosystems dominated by woody vegetation (dotted) and those dominated by nonwoody vegetation (solid). These relationships have been calculated from watershed data (Zhang et al. 2001) using a four-parameter logistic regression model in SigmaPlot version 7.0 (SPSS, Chicago, Illinois, USA). Three zones can be identified, each having distinct implications regarding the effects of woody plant encroachment on the hydrologic cycle. In arid zones $(P<350 \mathrm{~mm})$, all precipitation is essentially lost to the atmosphere, and differences (in ET/P) between woody and nonwoody systems are very small. In semiarid zones $(350 \mathrm{~mm}<P<800 \mathrm{~mm}$ ), the relative effect changes dramatically as a function of $P$. In subhumid zones $(P>800$ $\mathrm{mm})$, the relative effect of woody plants on ET/P is fairly constant.

scapes, attributable to the greater coverage of woody plants. As discussed below, these predicted differences are well supported in the literature. Even for semiarid landscapes, the model predicts a significant rise in ET as a percentage of precipitation. In this paper, we argue that there are important interactions among climatic, physiographic, and geomorphic conditions that control the effect woody plants have on the water budget of semiarid areas.

In humid landscapes (defined as those in which annual precipitation exceeds annual potential evapotranspiration), woody plants have a large effect on the water budget: they augment both transpiration and interception (Jarvis and McNaughton 1986, Crockford and Richardson 2000), which leads to lower streamflow. This inverse relationship between forest cover and streamflow has been clearly demonstrated for many forested landscapes (Bosch and Hewlett 1982, Trimble et al. 1987, Calder 1990). At the other extreme, in arid environments (those in which potential evapotranspiration is many times greater than precipitation), woody plants have comparatively little effect on the water budget-for the simple reason that most of the water in these landscapes is evaporated regardless of the vegetation cover (Wilcox et al. 2003).

Semiarid landscapes represent a transitional zone between humid environments, in which woody plants have a large effect, and arid ones, in which the effect is minimal. It is for the semiarid environments that the most confusion exists, and therefore the need for knowledge is most critical. The Zhang et al. (2001) model (Fig. 1) is based primarily on semiarid landscapes in which precipitation occurs predominantly during the winter when evaporative potential is low. In these climate zones (broadly referred to here as "Mediterranean-type," but inclusive of systems such as the cold deserts of North America), precipitation and potential evapotranspiration peak out of phase seasonally (precipitation is high when potential evapotranspiration is low). In fact, the grasslands-vs.-woodlands comparison in the Zhang et al. (2001) model for semirarid regions was validated primarily via two sets of data, both from regions having predominantly winter precipitation-California in the USA and Victoria in southwestern Australia (Turner 1991; J. W. Holmes and J. A. Sinclair, unpublished manuscript).

There are vast semiarid areas in non-"Mediterranean-type" climates for which the Zhang et al. (2001) model may not apply. In these landscapes, a change in woody plant coverage can have little effect on streamflow (see Table 1 for examples from the southwestern United States). The only plant communities in the southwestern United States that conform to the predictions of Fig. 1 are the chaparral communities, in which rainfall is above $600 \mathrm{~mm} / \mathrm{yr}$ and precipitation occurs during periods of low potential evapotranspiration (PET). This suggests that in semiarid landscapes, other factors-in addition to climate-determine how and to what extent vegetation cover influences the water budget. Empirical relationships between streamflow and woody plant cover, similar to that shown in Fig. 1 , have in fact been developed for shrublands (Bosch and Hewlett 1982, Hibbert 1983), but these are based largely on results from chaparral communities in Mediterranean climates. "Rules of thumb" from such relationships have been broadly and, we would argue, inappropriately applied to semiarid shrublands elsewhere.

Understanding the potential effect of woody plants on streamflow or groundwater recharge in semiarid regions requires an understanding of the processes that partition soil water into ET, runoff, and recharge. Streamflow is the passage of water through a defined and permanent channel, and as such is a landscape- or watershed-scale phenomenon. Because water may reach the stream channel through both surface and subsurface pathways (Dunne 1978), the explicit mechanism of streamflow generation must be known for the role of woody plants to be understood. Streamflow and groundwater recharge are often linked: perennial and intermittent streams have a baseflow component that is fed by groundwater. In contrast, transmission losses through the bed of intermittent streams may be substantial, and these losses are the primary source of recharge in some semiarid landscapes (Smakhtin 2001). 
TABLe 1. A summary of studies at sites in the western United States where the influence of woody plant cover on the water budget has been evaluated experimentally.

\begin{tabular}{|c|c|c|c|c|c|c|c|}
\hline \multirow[b]{2}{*}{$\begin{array}{l}\text { Dominant plant } \\
\text { or community }\end{array}$} & \multirow[b]{2}{*}{ Location } & \multirow[b]{2}{*}{$\begin{array}{l}\text { No. } \\
\text { sites }\end{array}$} & \multirow[b]{2}{*}{$\begin{array}{l}\text { Precipitation } \\
\quad(\mathrm{mm})\end{array}$} & \multicolumn{2}{|c|}{$\mathrm{ET} / P$} & \multirow[b]{2}{*}{ Method } & \multirow[b]{2}{*}{ Source } \\
\hline & & & & $\begin{array}{l}\text { High woody } \\
\text { plant }\end{array}$ & $\begin{array}{c}\text { Low woody } \\
\text { plant }\end{array}$ & & \\
\hline $\begin{array}{l}\text { Juniperus } \\
\text { osteosperma }\end{array}$ & $\begin{array}{l}\text { Beaver Creek, } \\
\text { Arizona }\end{array}$ & 2 & 458 & 0.97 & 0.96 & small watershed & $\begin{array}{l}\text { Clary et al. } \\
\text { (1974) }\end{array}$ \\
\hline $\begin{array}{l}\text { Juniperus } \\
\quad \text { deppeana }\end{array}$ & $\begin{array}{l}\text { Beaver Creek, } \\
\text { Arizona }\end{array}$ & 1 & 514 & 0.89 & 0.87 & small watershed & $\begin{array}{l}\text { Clary et al. } \\
\text { (1974) }\end{array}$ \\
\hline Chaparral & $\begin{array}{l}\text { Mingus, } \\
\text { Arizona }\end{array}$ & 2 & 480 & 0.99 & 0.98 & small watershed & $\begin{array}{l}\text { Hibbert } \\
\quad(1983)\end{array}$ \\
\hline Chaparral & $\begin{array}{r}\text { Whitespar, } \\
\text { Arizona }\end{array}$ & 1 & 589 & 0.92 & 0.9 & small watershed & $\begin{array}{l}\text { Hibbert } \\
\quad(1983)\end{array}$ \\
\hline Chaparral & $\begin{array}{r}\text { Three Bar, } \\
\text { Arizona }\end{array}$ & 3 & 673 & 0.92 & 0.77 & small watershed & $\begin{array}{l}\text { Hibbert } \\
\quad(1983)\end{array}$ \\
\hline $\begin{array}{l}\text { Prosopis gladu- } \\
\quad \text { losa }\end{array}$ & $\begin{array}{l}\text { Throckmorton, } \\
\text { Texas }\end{array}$ & 1 & 658 & 0.97 & 1 & soil lysimeter & $\begin{array}{l}\text { Carlson et } \\
\text { al. (1990) }\end{array}$ \\
\hline $\begin{array}{l}\text { Prosopis gladu- } \\
\quad \text { losa }\end{array}$ & Alice, Texas & 1 & 887 & 0.99 & 0.94 & soil lysimeter & $\begin{array}{l}\text { Weltz and } \\
\text { Black- } \\
\text { burn } \\
(1995)\end{array}$ \\
\hline Juniperus ashei & $\begin{array}{l}\text { Seco Creek, } \\
\text { Texas }\end{array}$ & 1 & 596 & 0.73 & 0.68 & Bowen ratio & $\begin{array}{l}\text { Dugas et al. } \\
\text { (1998) }\end{array}$ \\
\hline Juniperus ashei & Sonora, Texas & 1 & 574 & 0.99 & 0.83 & $\begin{array}{c}\text { small watershed, } \\
\text { soil lysimeter }\end{array}$ & $\begin{array}{c}\text { Thurow and } \\
\text { Hester } \\
(1997)\end{array}$ \\
\hline
\end{tabular}

Note: Evaportranspiration (ET) was determined using a number of experimental procedures. For the small-watershed studies, evaporation was determined by difference (precipitation minus runoff; $P-R$ ); for the soil lysimeter studies, evapotranspiration was determined by monitoring soil moisture and surface runoff; and for the Bowen ratio study, evapotranspiration was directly estimated. Water not evapotranspired would be available for runoff or recharge.

Woody vegetation may alter both surface and subsurface streamflow generation, with the relative abundance of vegetation determining the extent of alteration. Woody plants alter overland flow primarily by their influence on soil infiltration, which they can either increase or decrease (Wilcox 2002). They potentially alter subsurface flow either by intercepting precipitation, thus preventing water from reaching the soil; by increasing infiltration via stemflow and preferential root channels; and/or by transpiring water that would otherwise recharge groundwater and/or streams. It is these "tree-scale" findings that are often invoked to make a case for reducing or controlling woody plants as a means of increasing streamflow (Bednarz et al. 2001, Lemberg et al. 2002). However, significant increases in streamflow in semiarid landscapes through reduction of woody plant cover have been experimentally documented in only a few semiarid locations (Table 1).

Streams and rivers in drylands are somewhat of a contradiction; that is, on the basis of climate, they should not be present in drylands, where the "drying power" or potential evapotranspiration (PET) exceeds precipitation $(P)$. Such conditions imply that all precipitation will evaporate, leaving no water available for groundwater recharge or streamflow. But streams are found in many dryland ecosystems, even though they typically account for only a small fraction of the total water budget. Either they originate from some upstream, wetter location, or the $\mathrm{PET} / \mathrm{P}$ process is somehow "short-circuited." Short-circuiting may occur in a number of circumstances: (1) if the intensity of precipitation exceeds the soil infiltration capacity and overland loss of water occurs (Horton overland flow); (2) if the total amount of precipitation or snowmelt exceeds the capacity of the soil to store it, the result is saturated overland flow; and (3) if water passes through the soil and substrate before the vegetation can transpire all of it, the result is shallow subsurface flow and/or groundwater flow.

The interactions between woody plants and streamflow in drylands are complex, but some general linkages can be made, especially at the landscape scale (Fig. 2). At each hierarchical level, a distinction is made on the basis of availability of subsurface waterthe rationale being that if there is an excess of subsurface water, there is more opportunity for woody plants to modify the water cycle (particularly streamflow and groundwater recharge). The framework depicted in Fig. 2 is hierarchical or a decision tree. At each decision point a question is used to guide whether there is a low or high probability that woody-dominated vegetation differs from herbaceous vegetation in its effects on water yield.

\section{Level 1-physiographic distinction: is the physiographic setting riparian or upland?}

In assessing the influence of woody plants, perhaps the most important distinction is between riparian and upland landscapes. In riparian zones, woody plants 


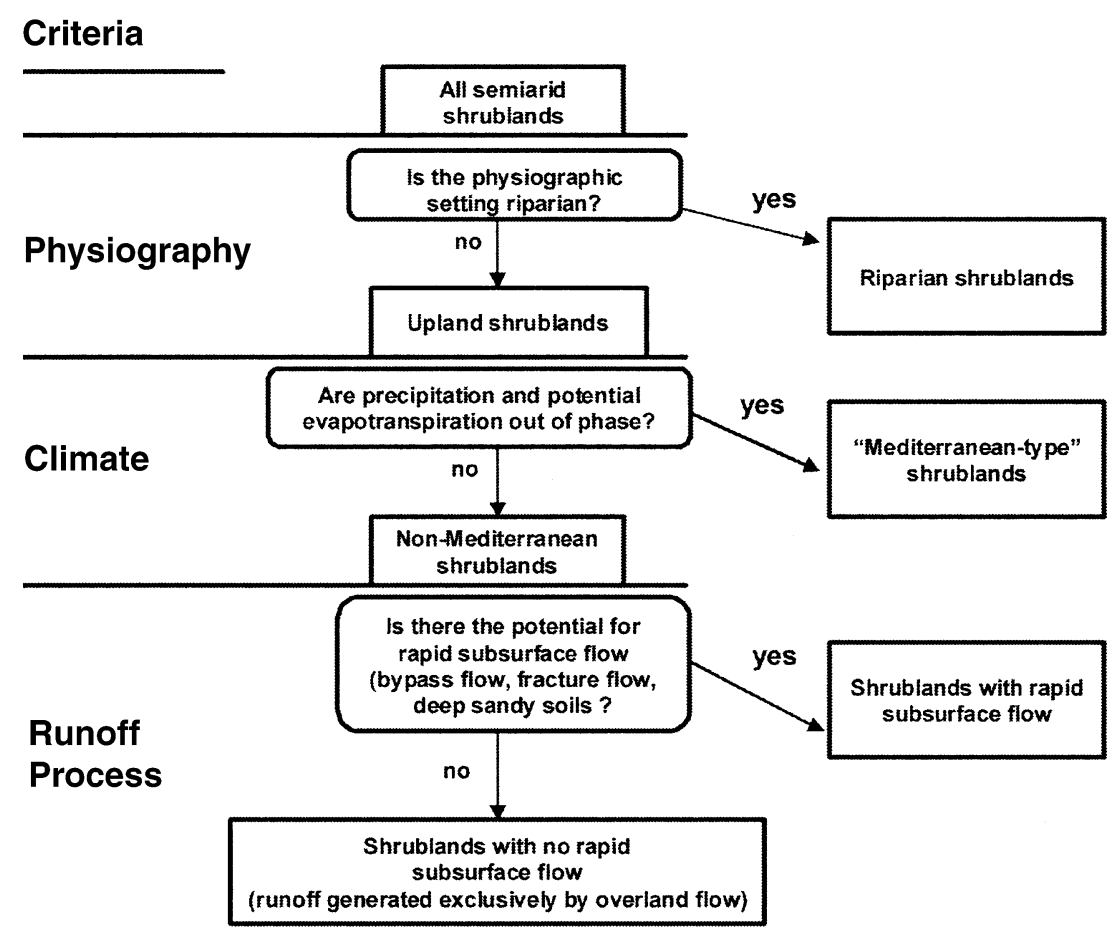

FIG. 2. Conceptual model 1: the probable connection between type of shrub cover and water yield. The boxes on the right side designate areas where the linkage with water yield (streamflow and/or appreciable recharge) is likely to be strongest.

have access to groundwater for a significant part of the year, whereas at upland sites water is limited by precipitation. Where woody plants are directly accessing water from saturated zones adjacent to stream channels, the potential exists for decreases in streamflow (Scott 1999, Scott et al. 2004). In the southwestern United States, the invasive shrub salt cedar (Tamarix sp.), which has spread along semiarid flood plains and stream channels over the last 50 years, is the best known example (Busch and Smith 1995, Cleverly et al. 1997). The economic costs of reduced streamflow and diminished channel capacity associated with salt cedar encroachment may be substantial (Zavaleta 2000).

\section{Level 2-climatic distinction: are P and PET out of phase?}

For upland (nonriparian) sites, understanding the influence of woody plants on streamflow requires a distinction based on climate, i.e., whether the evaporative demand exceeds $P$ for substantial portions of time; e.g., "Mediterranean-type" climates. When the evaporative demand exceeds $P$, there is generally no "surplus" of water (exceptions to this are discussed below). Conversely, when $P$ exceeds the evaporative demand, there is "surplus" water available for groundwater recharge or streamflow, even if only for a limited time. In humid landscapes, for example, average $P$ will exceed the evaporative demand, at least during some months or seasons of the year. Arid or semiarid landscapes, on the other hand, typically have climates such that the seasonal evaporative demand almost always exceeds $P$, often by many times. "Mediterranean-type" climate regions, where winter $P$ often exceeds the evaporative demand, is a major exception. Not coincidentally, it has been in this type of climate that dramatic increases in streamflow have been documented in response to the removal of chaparral shrubs (Ffolliott and Thorud 1974, Hibbert 1983). Similarly, removal of Eucalyptus scrub in southern Australia, where the climate is Mediterranean-like (high winter precipitation), has led to rising groundwater tables (Walker et al. 1993).

Level 3-runoff processes: is there the potential for rapid subsurface flow or deep drainage (bypass flow, fracture flow, or deep sandy soils)?

The final distinction required to understand the link between streamflow and woody plant cover is based on the nature of subsurface flow, which influences how runoff is generated. In some semiarid upland systems, runoff is generated only as Horton overland flow; in others, there is a subsurface component to runoff. Little or no recharge occurs in systems where there is no subsurface flow into stream channels and runoff is generated only when precipitation overwhelms the infiltration capacity of the soil (Horton overland flow). In contrast, in semiarid landscapes where subsurface flow does occur, it is often because the surface soils have 
TABLE 2. Estimates of the ratio of transpiration $(T)$ to evapotranspiration (ET) for several different semiarid and arid ecosystems based on different methodologies (empirical and modeling assessments).

\begin{tabular}{llcll}
\hline \hline Community type & Desert & MAP $\dagger(\mathrm{mm})$ & $T /$ ET $\ddagger$ & \multicolumn{1}{c}{ Source } \\
\hline Empirical assessments & & & & \\
Larrea & Chihuahuan & 230 & 72.0 & Schlesinger et al. (1987) \\
Larrea & Sonoran & 280 & 7.0 & Sammis and Gay (1979) \\
Mixed & Sonoran & 280 & $(5.0-25.0)$ & Evans et al. (1981) \\
Mixed shrub & Mojave & 150 & 35.0 & Smith et al. (1995) \\
Mixed shrub & Mojave & 50 & 53.0 & Stark (1970) \\
Ceratoides/Atriplex & Great Basin & 244 & 54.0 & Caldwell et al. (1977) \\
Prosopis & Sonoran & 343 & 85.0 & Yepez et al. (2003) \\
Modeling assessments & & & & \\
Mixed shrub & Chihuahuan & 230 & $(6.0-60.0)$ & Reynolds et al. (2000) \\
C & Grassland & 230 & $(1.0-58.0)$ & Reynolds et al. (2000) \\
Larrea & Chihuahuan & 250 & 80.0 & Liu et al. (1995) \\
Mixed shrub & Sonoran & 266 & 27.0 & Young and Nobel (1986) \\
Mixed shrub & Sonoran & 165 & $(15.0-37.0)$ & Lane et al. (1984) \\
Artemisia & Mojave & Campbell and Harris (1977) \\
\hline
\end{tabular}

$\dagger$ Mean annual precipitation.

$\ddagger$ Average reported ratio of transpiration to evapotranspiration, or (in parentheses) the range of ratios observed throughout multiple years.

limited storage capacity and the subsurface materials allow for the rapid movement of excess water. In such areas, subsurface flow is important for sustaining baseflow in streams and for groundwater recharge. A classic example is the Edwards Plateau of Texas, where soils are very shallow and overlie a fractured limestone parent material (Maclay 1995). These features explain why, in spite of the semiarid climate, perennial streams are abundant in this region (recharge to the underlying aquifer is abundant). Another example is that of mesquite growing on deep clays that crack when desiccated. If precipitation occurs when cracks are expressed at the surface, water may move rapidly beyond the rooting zone of herbaceous vegetation (Richardson et al. 1979). Similarly, water may move beyond the herbaceous rooting depth where deep sandy soils exist.

\section{Conceptual Model 2: Effects of Woody Plant \\ EnCroachment on Evaporative Processes}

As previously discussed, there are some semiarid environments in which changes in woody plant cover lead to changes in the magnitude of ET, which in turn translate to changes in streamflow. For many semiarid and arid landscapes, however, total ET is insensitive to changes in vegetation cover; nearly all the water that is available within a hydrologic year will be evaporated or transpired (Wilcox et al. 2003). Even so, changes in woody cover in such landscapes influence the characteristics of water loss through biological or physical means. For example, a change in woody plant cover may alter the relative contributions of plant transpiration to total system evapotranspiration (T/ET), which represents the relative contribution of ecological processes to hydrological fluxes. Mechanistically, T/ET links water balance processes with plant activity in a landscape. For example, we would expect ecosystems having a high $T / E T$ to be highly productive compared with ecosystems having a low $T / E T$ - especially if water transport through plants is proportional to growth rate and production (Enquist 2002). Indeed, modeling of $T / E T$ for a semiarid shrubland shows that the ratio varies from year to year as a result of seasonal patterns of precipitation, differential water use by grasses vs. shrubs, and the infrequent ET contribution of annual plants (Reynolds et al. 2000). Despite the fundamental importance of $T / E T$ to the ecological and hydrological dynamics of drylands, it has been estimated only for a relatively small number of locations in water-limited regions, and those field and modeling estimates vary greatly in methodology (Table 2; Reynolds et al. 2000, Wilson et al. 2001).

Does woody plant encroachment alter how $T$ and $E$ contribute to total evaporative flux, and if so, how? Few studies have explicitly examined this question, so here we develop hypotheses about how T/ET is affected by woody plant encroachment based on the limited field data and modeling results available, and based on documented and expected effects of woody plants on the system energy balance and water budget. Our hypotheses result from four basic assumptions relating climate and woody plants to soil water dynamics and evaporation.

Assumption I. Effect of climate on soil water dynamics.-Increasing precipitation from xeric to mesic systems results in greater depths of soil water infiltration and hence a smaller fraction of water at shallow depths where it is subject to evaporation (Loik et al. 2004; Fig. 3a).

Assumption II. Effect of climate on soil evaporation.-Increasing precipitation from xeric to mesic systems produces an associated increase in total vegetation cover, which results in reduced bare ground as a cover class (Schlesinger et al. 1990) and thus, decreased soil evaporation (Fig. 3b). 

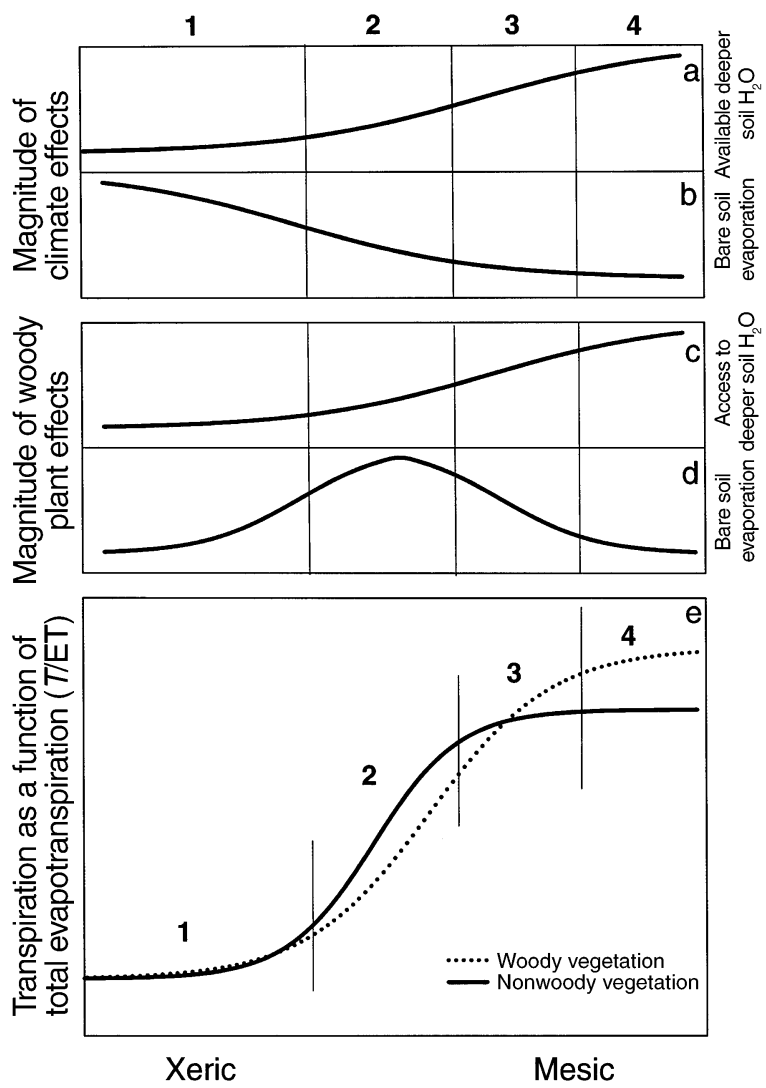

FIG. 3. Conceptual model 2: the relative change in the contribution of either transpiration $(T)$ or bare soil evaporation $(E)$ to total evapotranspirational flux (ET) for landscapes dominated by woody plants as compared to herbaceous vegetation across a climatic gradient. The processes underlying expected changes in $T$ relative to ET include aspects of climate (panels a and b) along with interactions that arise from woody vs. nonwoody plant presences (panels c and d). Relationships plotted are relative values either as a function of climate ("climate effects") or the presence of woody plants as compared to nonwoody plants ("woody plant effects"). (a) Increasing precipitation $(P)$ from arid to mesic systems increases infiltration depths resulting in a greater proportion of shallow available soil water subject to evaporation in arid regions. (b) Increasing $P$ from arid to mesic systems increases total vegetation cover resulting in smaller proportional contributions of $E$ to ET. (c) The ability of woody plants to access deep soil $\mathrm{H}_{2} \mathrm{O}$ increases $T$ in climates that allow for deep infiltration. (d) Increasing connectivity of bare soil patches and changes in bare soil energy balance result in increases in $E$ for midrange climates. As a result of these changes in flux components, the relative contribution of $T$ to ET will increase for systems dominated by woody plants as compared to those dominated by nonwoody plants in more mesic climate zones, with the opposite effect in semiarid systems. Four zones can be delimitated where changes in the $T / \mathrm{ET}$ are likely to occur. In Area 1, there is little change in T/ET because leaf area remains about the same and ET is dominated by $E$ from large expanses of bare ground. In Area 2, $E$ increases substantially in woody plant systems as a result of the loss of herbaceous cover in intercanopy spaces. Area 3 is a transition zone (no further changes in $T$ are being caused by woody plants, and herbaceous vegetation still dominates intercanopy spaces). In Area 4, differences in T/ET are due to increased $T$ by shrubs (shrubs are using "extra" water that, in a grassland system, would become groundwater recharge).
Assumption III. Effect of woody plants on soil water dynamics.-Woody plants are generally able to access sources of soil water that extend below the zone of soil evaporation in climates that produce such sources of soil water (Walter 1971, Breshears and Barnes 1999, House et al. 2003; Fig. 3c).

Assumption IV. Effect of woody plants on soil evaporation.-In more mesic systems, woody plant cover substantially reduces the near-ground solar radiation (Martens et al. 2000) and associated rates of soil evaporation (Breshears et al. 1998), with the magnitude of this effect increasing with the proportion of woody plants and with their mean height (Martens et al. 2000). However, in systems with greater water limitation, woody plant encroachment can result in a loss of herbaceous understory plants and greater connectivity and cover of bare-ground microsites (Small and Kurc 2003), which should increase potential soil evaporation (Fig. 3d).

Based on these four assumptions, we pose three general hypotheses. First, we hypothesize that woody plant encroachment should indeed alter the $T / \mathrm{ET}$ and the way in which $T / \mathrm{ET}$ is altered is largely driven by climate (assumptions I and II). More specifically, we hypothesize that, across a gradient of decreasing aridity, the $T / E T$ ratio should increase for both nonwoody and woody systems (Fig. 3e).

Second, we hypothesize that $T / E T$ in nonwoodyplant-dominated sites at the extreme ends of the gradient (zones 1 and 4 in Fig. 3) are less sensitive to changes in woody vegetation than sites that are intermediate within the continuum (semiarid sites in zones 2 and 3 of Fig. 3). For the subhumid sites (zone 4 of Fig. 3), assumption II-the effect of climate on soil evaporation-is critical: there will be nearly complete vegetation cover whether or not woody plants dominate, and hence evaporation is not likely to differ greatly between the two plant conditions. However, there should be more soil water below the evaporative zone for subhumid than for semiarid or arid systems, and hence woody plant access to this deeper water is expected to produce more $T$ and a greater $T / E T$ for woody as opposed to nonwoody systems (assumptions I and III). As a result, these climate regions tend to have greater leaf area (Scholes and Archer 1997), and more expansive root systems (Canadell et al. 1996, Jackson 1999, Gibbens and Lenz 2001) associated with woody plant dominance. For arid sites (zone 1 of Fig. 3), assumption II is also central: the smaller amounts of precipitation associated with arid sites leaves greater intercanopy bare soil microsites which are subject to high evaporation potential. Reduced precipitation minimizes deep soil water infiltration (assumption I) and the effects of shading by woody plants are reduced due to their sparseness and low stature (assumption IV). Further, because most of the precipitation does not infiltrate beyond the evaporative zone in these systems (as- 
sumption II), effects of woody plants on T/ET are minimal.

Third, for semiarid systems, which are intermediate along the gradient, the $T / \mathrm{ET}$ ratio is more sensitive to changes in woody plant coverage than it is for subhumid or arid systems, with wetter semiarid sites having greater $T / E T$ in woody than nonwoody systems (zone 3 of Fig. 3) and drier semiarid sites having less T/ET in woody than nonwoody systems (zone 2 of Fig. 3 ). As precipitation decreases from subhumid to semiarid zones, changes in soil evaporation due to climate and woody plants (assumptions II and IV) drive a reduction in the difference between woody vs. nonwoody systems (zone 3 of Fig. 3). For drier semiarid systems (zone 2 of Fig. 3), there is a transition from an increase in woody plants increasing $T$ and associated $T / E T$ to woody plants simply shifting acquisition of the $T$ from herbaceous to woody plants without producing a net change in $T / E T$ (assumption III). More importantly, in some cases changes in woody vegetation reduces the near-ground energy budget and associated soil evaporation, while in other cases it causes an enhancement and increase in soil evaporation (assumption IV).

The hypotheses we pose about how $T / E T$ varies along a gradient from subhumid to arid and for nonwoody versus woody vegetation provide an agenda for future research aimed at linking ecological and hydrological processes in water-limited climates. Both modeling and field studies are needed to more rigorously test the predictions and assumptions that they are based on. Nonetheless, we believe these hypotheses are based on assumptions that are both logical and supported by research to date. More generally, we believe that explicitly focusing on partitioning $T$ and $E$ represents one of the most important ecohydrological challenges if we are to improve our understanding of vegetation dynamics in drylands.

\section{VARIATION IN COMPONENTS OF THE HydRologic CyCle: ECOlOGicAl IMPlications}

The framework described above helps facilitate our understanding of the hydrological consequences of woody plant invasion. Building on this framework, we may also gain some insight into how woody plants affect other ecologically important processes, such as patterns and rates of biogeochemical cycling. It is likely that the carbon cycle, for example, is influenced in ways that are mechanistically linked to the effects of woody plant encroachment on water movement within a landscape. It has long been assumed that in grassland ecosystems, an increase in woody plant species results in greater accumulation of carbon from the atmosphere-owing to the ability of woody species to access water stored at depth and spatially redistribute it across the landscape, which increases plant biomass. Over time, the additional carbon from this distributed root biomass (Jackson et al. 1999, 2000) can sometimes transfer to long-term storage in the soil (Archer et al.
2001, Jackson et al. 2002). If this occurs, the effect on regional carbon cycles could be quite large considering the aerial extent of landscapes undergoing woody plant encroachment (Goodale and Davidson 2002), and it may be one of several important biotic feedbacks related to anthropogenic changes in the climate system (Schimel et al. 2001). However, as with the question of how woody plants affect the hydrologic cycle, the extent of changes in carbon accumulation and the magnitude of such changes are not clear (Archer et al. 2001, Jackson et al. 2002, Pacala et al. 2001).

It is generally accepted that an increase in the plantbiomass pool of carbon is a consequence of woody plant encroachment, but for carbon sequestration to increase in an ecosystem, net ecosystem production (NEP) must increase-a process that is poorly understood for these landscapes (House et al. 2003). NEP is the difference between gross primary production (GPP: the absolute amount of carbon entering an ecosystem through autotrophic means) and ecosystem respiration $\left(R_{\mathrm{e}}\right.$ : the absolute loss of carbon through autotrophic and heterotrophic metabolic activity), both of which are intimately linked to the hydrologic cycle. Given that plant $T$ can be considered directly proportional to GPP (Enquist 2002), we can suggest, on the basis of the hypothesized changes in $E$ and $T$, how biomass production may vary with woody plant encroachment. Further, since $R_{\mathrm{e}}$ is primarily a function of temperature and the availability of resources (Enquist et al. 2003; in this case, primarily soil water content), shifts in the seasonal availability of water can be used to predict changes in carbon efflux. Thus, through the linkage with water processes and their effect on NEP, our conceptual framework allows us to predict how woody plant species may influence the influx and efflux of carbon from an ecosystem.

We have suggested that, in arid ecosystems, $T$ may not shift significantly with woody plant encroachment, which would translate to little or no change in GPP other than greater carbon accumulation in the pool of plant biomass. However, woody plant species tend to have longer seasonal periods of active water extraction than do grassland species (Kemp 1983, Smith et al. 1997) and thus can reduce soil water content consistently throughout a year (Kemp 1983, Scott et al. 2000). As a result, in arid shrubland ecosystems $R_{\mathrm{e}}$ may become constrained by the availability of soil water (duration and magnitude) for longer periods than in arid grassland systems. Thus, while the influx of carbon may not be very different between shrubland and grassland ecosystems (or may differ only as a function of the different allocation patterns of shrubs vs. grasses), the efflux of carbon may be lowered by extended periods during which soil water content is limited. In other words, from a simplistic influx-efflux perspective as the processes are linked to the soil water, woody plant encroachment in arid systems brings the potential

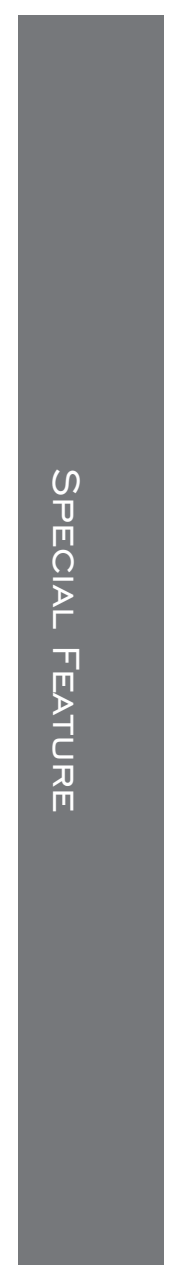


for relatively greater accumulation of carbon in soils (Jackson et al. 2002).

In many mesic ecosystems, woody plant encroachment increases $T$, which results in greater ET. As suggested in Fig. 1, the woody plants take up water (which, in a grassland system, would have left the landscape as streamflow) and transform it into biological activity, thereby increasing GPP. While this greater influx of carbon is straightforward to predict, changes in carbon efflux, or $R_{\mathrm{e}}$, may depend on several additional factors that determine soil water content (similar to the hierarchical model in Fig. 2). Where the seasonal pattern of soil water availability is not reduced by woody plant encroachment (streamflow still exists within the system following the establishment of woody plants), $R_{\mathrm{e}}$ should remain constant or simply increase in proportion to the total ecosystem biomass. Where climatic conditions are such that streamflow is reduced significantly by woody plant encroachment, giving rise to frequent periods of low soil water content, $R_{\mathrm{e}}$ will be constrained, as it is in arid systems. If, through time, GPP sees a net increase and $R_{\mathrm{e}}$ a net decrease, these systems could become carbon sinks. This thought exercise does not consider explicitly differences in biomass allocation between grasslands and shrublands, differences in the input of different quality litter, feedbacks on nitrogen cycling from decomposition processes. However, as such, this pattern is consistent with the relationship observed by Jackson et al. (2002), between soil carbon content and climate, for a series of sites in the southwestern United States characterized by woody plant encroachment where proportionally greater carbon accumulation is seen in more arid sites.

Several additional factors should be very important in determining the balance between carbon influx and efflux for a given system. In semiarid ecosystems, yearto-year variability in precipitation and the presence/ activity of different life forms influence not only the input of carbon into the system but also efflux, by affecting the seasonal pattern of soil water availability. For example, changes in the distribution of water under shrub canopies, from diffuse to preferential infiltration (Devitt and Smith 2002, Bhark and Small 2003), will alter soil water availability, magnifying differences in the sensitivities of carbon processes to changes in vegetation structure. In more mesic areas, woody species often do not replace grass and intercanopy zones remain occupied by herbaceous vegetation. The presence of different vegetation types having different seasonal activity profiles further complicates the dynamics of carbon input into soils and its linkages with soil water. At the landscape scale, $R_{\mathrm{e}}$ will depend on the magnitude of canopy/intercanopy respiration flux, scaled by the spatial extent of intercanopy vs. canopy space. Resolving the partitioning of $E$ and $T$ and the potential degree of decoupling of GPP from precipitation should help to clarify the net effect of woody plant encroach- ment on NEP at the landscape scale, allowing us to understand potential changes in carbon storage.

\section{Summary AND CONCLUSIONS}

The fact that woody plant encroachment has the potential to change how water moves through semiarid and arid landscapes has important implications for hydrology, ecology, and society. We have proposed a framework for understanding how woody plant encroachment is likely to affect components of the water budget within dryland ecosystems. How recharge/runoff and evaporative processes are affected will depend on the degree of aridity within a given landscape and the availability of subsurface water. By using two conceptual models that focus on different features of a simple water-balance model and their component variables, we are able to make several important generalizations that have been missing from the field to date.

1) From a hierarchical comparison of different landscape physiographies, climate, and runoff mechanisms (nature of subsurface flow), it can be conceptualized that woody plants have the potential to modify streamflow/runoff/recharge when subsurface water is available.

2) Shifts in the ratio of plant transpiration $T$ to total evapotranspiration ET can be expected when evaporative leaf area, volume of root systems, and duration of physiological activity are influenced by the presence of woody plant species within a landscape. Large shifts are more likely to occur in semiarid environments than in either more mesic (subhumid) or more xeric (arid) landscapes, where the increasing influence of bare ground and surface energy budgets on evaporation is linked to woody plant presence.

3) Predicted changes in the hydrologic cycles can be used to evaluate the influx and efflux of carbon for different climate-vegetation combinations, as a means of understanding NEP under conditions of woody plant encroachment. Where the proportional change in $T$ is large (increase in GPP) and the additional water use by plants results in reduced seasonal soil water content (limiting $R_{\mathrm{e}}$ ), woody plant encroachment can lead to increases in carbon accumulation in an ecosystem. Where soil water content or $T$ are unaffected by woody plant encroachment, losses of carbon from the ecosystem are possible.

It is important and necessary to consider such ecological and biogeochemical consequences of shifts in the hydrologic cycle when assessing the effects of different climate scenarios on biosphere function. Our conceptual models illustrate how, in one case, ecological processes (changes in vegetation structure) can influence hydrology (water yield; model 1) and how, in another case, hydrological characteristics (ratio of $E$ and $T$ ) have important ecological implications (pro- 
ductivity; model 2). Moreover, there are a number of other important ecohydrological interactions that will also affect hydrology and biogeochemistry through other avenues, not solely first-order functions of shifts in our simple water-balance model. These interactions represent critical areas for which research generalizations may be developed-especially through an interdisciplinary ecohydrological approach.

\section{ACKNOWLEDGMENTS}

The authors of this paper would like to acknowledge the participants of the 2002 Chapman Conference on Ecohydrology and their role in fostering many of the ideas presented here. Support was provided in part by the Biological and Environmental Research (BER) Program of the U.S. Department of Energy, through the Southcentral Regional Center of NIGEC, the International Arid Lands Consortium and the University of Arizona. This material is based upon work partially supported by SAHRA (Sustainability of semi-Arid Hydrology and Riparian Areas) under the STC Program of the National Science Foundation, Agreement No. EAR-9876800.

\section{Literature Cited}

Archer, S., T. W. Boutton, and K. A. Hibbard. 2001. Trees in grasslands: biogeochemical consequences of woody plant expansion. Pages 115-138 in E. D. Schulze, M. Heimann, S. Harrison, E. Holland, J. Lloyd, I. C. Prentice, and D. Schimel, editors. Global biogeochemical cycles in the climate system. Academic Press, Durham, North Carolina, USA.

Bednarz, S. T., T. Dybala, R. S. Muttiah, W. Rosenthal, and W. A. Dugas. 2001. Brush/water yield feasibility studies. Blackland Research Center, Temple, Texas, USA.

Bhark, E. W., and E. E. Small. 2003. Association between plant canopies and the spatial patterns of infiltration in shrubland and grassland of the Chihuahuan desert, New Mexico. Ecosystems 6:185-196.

Bosch, J. H., and J. D. Hewlett. 1982. A review of catchment experiments to determine the effect of vegetation changes and water yield and evapotranspiration. Journal of Hydrology 55:3-23.

Breshears, D. D., and F. J. Barnes. 1999. Interrelationships between plant functional types and soil moisture heterogeneity for semiarid landscapes within the grassland/forest continuum: a unified conceptual model. Landscape Ecology 14:465-478.

Breshears, D. D., J. W. Nyhan, C. E. Heil, and B. P. Wilcox. 1998. Effects of woody plants on microclimate in a semiarid woodland: soil temperature and evaporation in canopy and intercanopy patches. International Journal of Plant Sciences 159:1010-1017.

Busch, D. E., and S. D. Smith. 1995. Mechanisms associated with decline of woody species in riparian ecosystems of the southwestern U.S. Ecological Monographs 65:347-370.

Calder, I. R. 1990. Evaporation in the uplands. John Wiley and Sons, New York, New York, USA.

Caldwell, M. M., R. S. White, R. T. Moore, and L. B. Camp. 1977. Carbon balance, productivity and water use of coldwinter desert shrub communities dominated by $\mathrm{C}_{3}$ and $\mathrm{C}_{4}$ species. Oecologia 29:275-300.

Campbell, G. S., and G. A. Harris. 1977. Water relations and water use patterns for Artemisia tridentata Nutt. in wet and dry years. Ecology 58:652-659.

Canadell, J., R. B. Jackson, J. R. Ehleringer, H. A. Mooney, O. E. Sala, and E. D. Schulze. 1996. Maximum rooting depth of vegetation types at the global scale. Oecologia 108:583-595.

Carlson, D. H., T. L. Thurow, R. W. Knight, and R. K. Heitschmidt. 1990. Effect of honey mesquite on the water balance of Texas Rolling Plains rangeland. Journal of Range Management 43:491-496.

Chapin, F. S., P. A. Matson, and H. A. Mooney. 2002. Principles of terrestrial ecosystem ecology. Springer-Verlag, New York, New York, USA.

Clary, W. P., M. B. J. Baker, P. F. O'Connell, T. N. Johnson, and R. E. Campbell. 1974. Effects of pinyon-juniper removal on natural resources products and uses in Arizona. USDA Forest Service, Fort Collins, Colorado, USA.

Cleverly, J. R., S. D. Smith, A. Sala, and D. A. Devitt. 1997. Invasive capacity of Tamarix ramosissima in a Mojave Desert floodplain: the role of drought. Oecologia 111:12-18.

Crockford, R. H., and D. P. Richardson. 2000. Partitioning of rainfall into throughfall, stemflow, and interception: effect of forest type, ground cover and climate. Hydrological Processes 14:2903-2920.

Devitt, D. A., and S. D. Smith. 2002. Root channel macropores enhance downward movement of water in a Mojave Desert ecosystem. Journal of Arid Environments 50:99108.

Dugas, W. A., R. A. Hicks, and P. Wright. 1998. Effect of removal of Juniperus ashei on evapotranspiration and runoff in the Seco Creek Watershed. Water Resources Research 34:1499-1506.

Dunne, T. 1978. Field studies of hillslope flow processes. Pages 227-293 in M. J. Kirby, editor. Hillslope hydrology. John Wiley and Sons, New York, New York, USA.

Enquist, B. J. 2002. Universal scaling in tree and vascular plant allometry: toward a general quantitative theory linking plant form and function from cells to ecosystems. Tree Physiology 22:1045-1064.

Enquist, B. J., E. P. Economo, T. E. Huxman, A. P. Allen, D. D. Ignace, and J. F. Gillooly. 2003. Scaling metabolism from organisms to ecosystems. Nature 423:639-642.

Evans, D. D., T. W. Sammis, and D. R. Cable. 1981. Actual evapotranspiration under desert conditions. Pages 195-218 in D. D. Evans and J. L. Thames, editors. Water in desert ecosystems. Downden, Hutchinson, \& Ross, Inc., Stroudsburg, Pennsylvania, USA.

Ffolliott, P. F., and D. B. Thorud. 1974. Vegetation management for increased water yield in Arizona. Technical Bulletin 215. University of Arizona, Agricultural Experiment Station, Tucson, Arizona, USA.

Gibbens, R. P., and J. M. Lenz. 2001. Root systems of some Chihuahuan Desert plants. Journal of Arid Environments 49:221-263.

Goodale, C. L., and E. A. Davidson. 2002. Uncertain sinks in the shrubs. Nature 418:593-594.

Grover, H. D., and H. B. Musick. 1990. Shrubland encroachment in southern New Mexico, U.S.A.: an analysis of desertification processes in the American Southwest. Climate Change 17:305-330.

Hibbert, A. R. 1983. Water yield improvement potential by vegetation management on western rangelands. Water Resources Bulletin 19:375-381.

Houghton, J. T., Y. Ding, D. J. Griggs, M. Noguer, P. J. van der Linden, and D. Xiaosu, editors. 2001. Climate change 2001: the scientific basis. Cambridge University Press, Cambridge, UK.

Houghton, R. A., J. L. Hackler, and K. T. Lawrence. 1999. The US carbon budget: contributions from land-use change. Science 285:574-578.

House, J. I., et al. 2003. Conundrums in mixed woody herbaceous plant systems. Journal of Biogeography 30:17631777.

Jackson, R. B. 1999. The importance of root distributions for hydrology, biogeochemistry, and ecosystem functioning. Pages 217-238 in J. Tenhunen and P. Kabat, editors. Integrating hydrology, ecosystem dynamics, and biogeo-

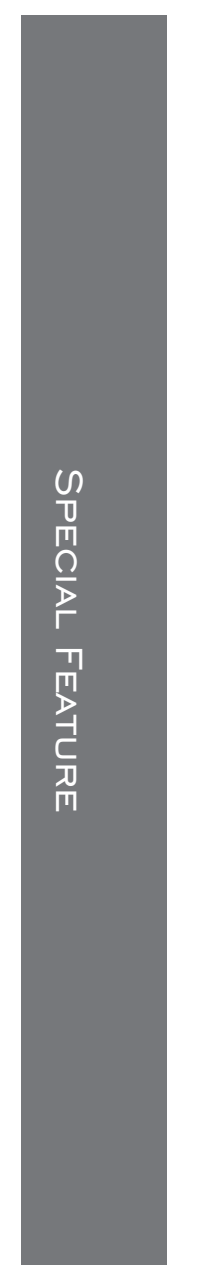


chemistry in complex landscapes. John Wiley and Sons, New York, New York, USA.

Jackson, R. B., J. B. Banner, E. G. Jobbagy, W. T. Pockman, H. Diana, and D. H. Wall. 2002. Ecosystem carbon loss with woody plant invasion of grasslands. Nature 418:623626.

Jackson, R. B., L. A. Moore, W. A. Hoffmann, W. T. Pockman, and C. R. Linder. 1999. Ecosystem rooting depth determined with caves and DNA. Proceedings of the National Academy of Sciences (USA) 96:11387-11392.

Jackson, R. B., et al. 2000. Belowground consequences of vegetation change and their treatment in models. Ecological Applications 10:470-483.

Jarvis, P. G., and K. G. McNaughton. 1986. Stomatal control of transpiration: scaling up from leaf to region. Advances in Ecological Research 15:1-49.

Kemp, P. R. 1983. Phenological patterns of Chihuahuan Desert plants in relation to the timing of water availability. Journal of Ecology 71:427-436.

Lane, L. J., E. M. Romney, and T. E. Hakonson. 1984. Water balance calculations and net production of perennial vegetation in the northern Mojave Desert. Journal of Range Management 37:12-18.

Lemberg, B., J. W. Mjelde, J. R. Conner, R. C. Griffin, W. D. Rosenthal, and J. W. Stuth. 2002. An interdisciplinary approach to valuing water from brush control. Journal of the American Water Resources Association 38:409-422.

Liu, B. L., F. Phillips, S. Hoines, A. R. Campbell, and P. Sharma. 1995. Water movement in desert soil traced by hydrogen and oxygen isotopes, chloride, and chlorine-36, southen Arizona. Journal of Hydrology 168:92-110.

Loik, M. E., D. D. Breshears, W. K. Lauenroth, and J. Belnap. 2004. A multi-scale perspective of water pulses in dryland ecosystems: climatology and ecohydrology of the western USA. Oecologia doi:10.1007/s00442-004-1570-y.

Maclay, R. W. 1995. Geology and hydrology of the Edwards aquifer in the San Antonio area, Texas. Water-Resources Investigations Report 95-4186. U.S. Geological Survey, Austin, Texas, USA.

Martens, S. N., D. D. Breshears, and C. W. Meyer. 2000. Spatial distributions of understory light along the grassland/forest continuum: effects of cover, height, and spatial pattern of tree canopies. Ecological Modeling 126:79-93.

Pacala, S. W., et al. 2001. Consistent land- and atmospherebased US carbon sink estimates. Science 292:2316-2320.

Reynolds, J. F., P. R. Kemp, and J. D. Tenhunen. 2000. Effects of long-term rainfall variability on evapotranspiration and soil water distribution in the Chihuahuan Desert: a modeling analysis. Plant Ecology 150:145-159.

Richardson, C. W., E. Burnett, and R. W. Bovey. 1979. Hydrologic effects of brush control on Texas rangelands. Transactions of the ASAE 22:315-319.

Sammis, T. W., and L. Y. Gay. 1979. Evapotranspiration from an arid zone plant community. Journal of Arid Environments 2:313-321.

Schimel, D. S., et al. 2001. Recent patterns and mechanisms of carbon exchange by terrestrial ecosystems. Nature 414: 169-172.

Schlesinger, W. H., P. J. Fonteyn, and G. M. Marion. 1987. Soil moisture content and plant transpiration in the Chihuahuan Desert of New Mexico. Journal of Arid Environments 12:119-126.

Schlesinger, W. H., J. F. Reynolds, G. L. Cunningham, L. F. Huenneke, W. M. Jarrell, R. A. Virginia, and W. G. Whitford. 1990. Biological feedbacks in global desertification. Science 247:1043-1048.

Scholes, R. J., and S. R. Archer. 1997. Tree-grass interactions in savannas. Annual Review of Ecology and Systematics 28:517-544.
Scott, D. F. 1999. Managing riparian zone vegetation to sustain streamflow: results of paired catchment experiments in South Africa. Canadian Journal of Forest ResearchJournal Canadien de la Récherche Forestière 29:11491157.

Scott, R. L., E. A. Edwards, W. J. Shuttleworth, T. E. Huxman, C. Watts, and D. C. Goodrich. 2004. Interannual and seasonal variation in fluxes of water and carbon dioxide from a riparian woodland ecosystem. Journal of Agriculture and Forest Meteorology 122:65-84.

Scott, R. L., W. J. Shuttleworth, T. O. Keefer, and A. W. Warrick. 2000. Modeling multiyear observations of soil moisture recharge in the semiarid American Southwest. Water Resources Research 36:2233-2247.

Seyfried, M. S., S. Schwinning, M. A. Walvoord, W. T. Pockman, B. D. Newman, R. B. Jackson, and F. M. Phillips. 2005. Ecohydrological control of deep drainage in arid and semiarid regions. Ecology 86:277-287.

Smakhtin, V. U. 2001. Low flow hydrology: a review. Journal of Hydrology 240:147-186.

Small, E., and S. Kurc. 2003. Tight coupling between soil moisture and the surface radiation budget in semiarid environments: implications for land-atmosphere interactions. Water Resources Research 39:2178.

Smith, S. D., C. A. Herr, K. L. Leary, and J. M. Piorkowski. 1995. Soil-plant water relations in a Mojave Desert mixed shrub community: a comparison of three geomorphic surfaces. Journal of Arid Environments 29:339-351.

Smith, S. D., R. K. Monson, and J. E. Anderson. 1997. Physiological ecology of North American desert plants. Springer-Verlag, New York, New York, USA.

Stark, N. 1970. Water balance of some warm desert plants in a wet year. Journal of Hydrology 10:113-126.

Stednick, J. D. 1996. Monitoring the effects of timber harvest on annual water yield. Journal of Hydrology 176:79-95.

Thurow, T. L., and J. W. Hester. 1997. How an increase or a reduction in juniper cover alters rangeland hydrology. Pages 9-22 in C. Taylor, editor. Juniper Symposium Proceedings. Texas A\&M University, San Angelo, Texas, USA.

Trimble, S. W., F. H. Weirich, and B. L. Hoag. 1987. Reforestation and the reduction of water yield on the Southern Piedmont since circa 1940. Water Resources Research 23: 425-437.

Turner, K. M. 1991. Annual evapotranspiration of native vegetation in a Mediterranean-type climate. Water Resources Bulletin 27:1-6.

Walker, J., F. Bullen, and B. G. Williams. 1993. Ecohydrological changes in the Murray-Darling Basin. I. The number of trees cleared over two centuries. Journal of Applied Ecology 30:265-273.

Walter, H. 1971. Ecology of tropical and subtropical vegetation. Oliver and Boyd, Edinburgh, UK.

Weltz, M. A., and W. H. Blackburn. 1995. Water budget for south Texas rangelands. Journal of Range Management 48: $45-52$.

Wilcox, B. P. 2002. Shrub control and streamflow on rangelands: a process-based viewpoint. Journal of Range Management 55:318-326.

Wilcox, B. P. 2003. Runoff from rangelands: the role of shrubs. In A. McGinty, C. W. Hanselka, D. N. Ueckert, W. Hamilton, and M. Lee, editors. Shrub management. Texas A\&M University, College Station, Texas, USA.

Wilcox, B. P., M. S. Seyfried, and D. D. Breshears. 2003. The water balance on rangelands. Pages 791-794 in B. A. Stewart and T. A. Howell, editors. Encyclopedia of water science. Marcel Dekker, New York, New York, USA.

Wilson, K. B., P. J. Hanson, P. J. Mulholland, D. D. Baldocchi, and S. D. Wullschleger. 2001. A comparison of methods for determining forest evapotranspiration and its compo- 
nents: sap-flow, soil water budget, eddy covariance and catchment water balance. Agricultural and Forest Meteorology 106:153-168.

Yepez, E., D. Williams, R. Scott, and G. Lin. 2003. Partitioning overstory and understory evapotranspiration in a semi-arid savanna ecosystem from the isotopic composition of water vapor. Agricultural and Forest Meteorology 119 : 53-68.
Young, D. R., and P. S. Nobel. 1986. Predictions of soilwater potentials in the northwestern Sonoran Desert. Journal of Ecology 74:143-154.

Zavaleta, E. 2000. The economic value of controlling an invasive shrub. Ambio 29:462-467.

Zhang, L., W. R. Dawes, and G. R. Walker. 2001. Response of mean annual evapotranspiration to vegetation changes at catchment scale. Water Resources Research 37:701-708. 